\title{
Influence of Human Resource Planning Practices on Lecturers' Performance in Kenyan Public Universities
}

\author{
Wyckliffe Otieno Robby ${ }^{1 *}$ Dr. Fredrick Aila ${ }^{2}$ Prof. Isaac Ochieng ${ }^{3}$ \\ 1. Department of Business Administration, Maseno University, P.O. Box 333-40105, Maseno, Kenya \\ 2. Department of Business Administration, Maseno University, P.O. Box 333-40105, Maseno, Kenya \\ 3. Department of Commerce, Laikipia University P.O. Box 1100-20300, Nyahururu - Kenya \\ *Email of the Corresponding Author: robirowa@gmail.com
}

\begin{abstract}
Kenya Vision 2030 envisions provision of globally competitive quality education, training and research to citizens. Despite public universities' contribution to this mandate, stakeholders such as World Bank, Commission for University Education, employers and scholars fault the quality and relevance of some academic programmes. The decline in quality is attributed to increased workload, reduced rigour in recruitment and promotion criteria, inability to attract and retain quality staff, and lecturers' alleged incompetence. Previous studies relating human resource planning (HRP) practices to employee performance (EP) do not use descriptors of HRP like business plans, scenario planning, demand and supply forecasting, forecasting future requirements and action planning in entirety in addition to exhibiting mixed findings. This study intended to establish influence of HRP on lecturers' performance in Kenyan public universities. It is anchored on Simon's Decision Making Theory and supported by Barney's Resource Based View; Adam Smith's Human Capital Theory; and Herzberg's Two-Factor Theory and implemented using descriptive cross-sectional survey research design. Target population comprised 1,653 lecturers in 14 chartered public universities established between 2009 and 2019. Multi-stage purposeful sampling technique was adopted to finally take a census of 158 academic heads of departments (lecturers) from 13 out of the 14 universities, having used 20 in piloting. Public universities account for $72 \%$ of the total university teaching staff hence the interest. Primary data were collected using semi-structured questionnaires while secondary data obtained from relevant secondary sources. Cronbach's alpha coefficient was used to examine the internal consistency at $0.796(S D=0.067)$. While content validity was ascertained by reviewing literature within the domain of study concepts and corroborated by a panel of experts, Pearson's $r$ was used to measure construct validity. Data were analyzed using Pearson's $r$ and regression analysis. The correlation between human resource planning (HRP) practice and lecturers' performance was established to be positive and significant $(r=.528$, $p=.000$ ) HRP practice accounted for $38.0 \%$ (Adjusted $R^{2}=.380$ ) of the variation in the lecturers' performance in Kenyan public universities implying that it can predict their performance. The findings are useful to the management of public universities, HRM practitioners, researchers, organizational behaviourists and theorists.
\end{abstract}

Keywords: Business plans, scenario planning, demand forecasting, supply forecasting, forecasting future requirements.

DOI: $10.7176 / \mathrm{EJBM} / 13-18-13$

Publication date:September $30^{\text {th }} 2021$

\section{Introduction}

Higher education lies at the nexus of growth, jobs, and competiveness and has the potential to catalyze economic transformation by supporting the lower levels of education, preparing professionals and skilled labour, and serving as an incubator for research (World Bank, 2017). In accord, the Kenya Vision 2030 envisions the provision of globally competitive quality education, training and research to her citizens for development and individual wellbeing (Republic of Kenya, 2007) with the public universities being one of the agents. Global higher education is experiencing a myriad challenges that impact performance and application of education throughout the world (Lemoine, Jenkins \& Richardson, 2017).

Generally, concerns have emerged regarding the quality and relevance of higher education, value for money and resource allocation in the sector (World Bank, 2017). Higher education incorporates a wider range of higher learning institutions including the university (Alemu, 2018). Academic standard of products from the university system has progressively taken a downward trend across most African countries (Agaruwhe and Ugborugbo, 2009; Alderman, 2010; Bisht, 2015; Ishaya, 2016; Adeyemi, 2017). The declining quality in African universities is manifested through falling student scores in examinations, reduced rigour on recruitment and promotion criteria, diminished research and complaints by employers on the incapability of university graduates to perform optimally (World Bank, 1996). 
In Kenya, whereas university education seeks to advance knowledge through quality teaching, scholarly research and scientific investigation (Republic of Kenya, 2012; Commission for University Education, 2016), stakeholders have faulted the quality and relevance of the programmes offered in Kenyan universities (Yego, 2016; Kaburu, 2014, Martin \& Anthony, 2007; Ajayi, 1996) much as they commend the increased access to university education. In particular, Kenyan university graduates have been accused of failing to exhibit the desired skills, knowledge and attitudes (Kala, Tanui \& Kalai, 2020; Ponge, 2013; Amimo, 2012; Kamaara, 2011; Riechi, 2010). Confirming these misgivings, a World Bank Report entitled 'Kenya's Education Achievement and Challenges' faults her education system for not producing graduates with the knowledge and skills that are considered crucial for Kenya Vision 2030 (Wanzala, 2015).

Extant literature demonstrates that quality of education, training and learning received by a student is domiciled in the quality of lecturers among other factors (Kala, Tanui and Kalai, 2020; UNICEF, 2000; Wanzala, 2013). Quality can be gauged in terms of calibre and sufficiency of academic staff, learning and teaching facilities, contact hours, entry behaviour of learners and governance structures - variables that they observed to be lacking in universities (Oanda and Jowi, 2012). Students' academic performance has been linked over time with the effectiveness of the teacher (lecturer) in terms of teaching and learning (Ajao, 2001). This decline is, therefore, attributable to increased workload and alleged incompetence of lecturers thus the interest in their performance amidst the declining quality (Ngolovoi, 2006). Collectively, these mirror the challenges that public universities face with respect to human resourcing practices such as human resource planning relative to lecturers' performance.

This study, therefore, sought to examine influence of human resource planning practice on lecturers' performance in Kenyan public universities. The interest in public universities arose from the fact that they account for $72 \%$ of the total university teaching staff (Commission for University Education, 2016). Specifically, chartered public universities established between 2009 and 2019 were targeted because of the staffing challenges they are faced with (Ikama, 2010) and pressure exerted on them to provide employment (Mukhwana, Oure, Too \& Some, 2016). It was anchored on decision-making theory (Simon, 1945; Mintzberg, 1973; Iyayi, 2002) and supported by the resource based view (Barney, 1991), human capital theory (Adam Smith 1723-1790) and the two-factor theory (Hezberg et al., 1957).

\section{Literature Review}

\subsection{Review of Theoretical Literature}

\subsubsection{Theoretical Foundation}

The study was anchored on Simon's decision making theory and supported by Barney's resource based view and Adam Smith's human capital theory. Decision-making theory has its roots in the studies by Simon (1945), Mintzberg (1973) and Iyayi (2002) on decision making in organizations. It is based on the fact that decisionmaking is at the very heart of business success in any organization; whole concept and purpose of organizations revolve around decision making (Gberevie, 2006; Tonwe 1994). Decision-making theorists hold that decisions are the selection of a proposed course of action (Butler, 1992; Iyayi, 2002). Such decisions could be around many human resource management practices including human resource planning which theoretically relates to employee performance. In so far as human resource planning is concerned, managers may have to make decisions in the following areas, amongst others: the direction that the business is going to take and its attendant implication on the human resources; possible intervention strategies in respect of different scenarios they may have to contend with; the most appropriate demand forecasting technique(s); the most appropriate source(s) of candidates for filling in vacancies; and the most appropriate action plan to take in cases of either surpluses or deficits in addition to possible retention and/or flexibility strategies they may adopt in the best interest of the organization.

The resource based view, attributed to Barney (1991), regards human resources as a key factor towards the attainment of competitive advantage and achievement of goals or targets for organizations (Barney, 2001). The theory holds the view that the strategic capability of an organization is domiciled in its resource capability in the shape of people (Armstrong, 2009). While organizational resources abound, Barney (1991) argues that HRM adds value through the strategic development of the organization's rare, hard to imitate and hard to substitute human resources. The relevance of this theory in this study is its focus on the quality of human resources available to an organization and their ability to adapt more quickly than their competitors (Katua and Gachunga, 2014). Barney (2001) proposes that firms constantly evaluate their workforce to ensure that they have the right people with the right skills in the right places to ensure sustained competitive advantage. When this is not the 
case, firms should make-up for the shortfall by employing appropriate recruitment and selection criteria (Ekwaoba, Ikeije and Ufoma, 2015) or, in the alternative, enhance the knowledge, skills and abilities of the existing resources through training and development.

Human capital theory whose proponent is Adam Smith (1723 - 1790) holds that people are fixed capitals, just like machines given that they have useful skills and abilities that have costs and yield profits (Teixeira, 2002). The theory intimates that sustainable competitive advantage is attained when the firm has a human resource pool that cannot be imitated or substituted by its rivals. It is premised on the assertion that people and their collective skills, abilities and experience, coupled with their ability to deploy these in the interest of the firm contribute to its competitive advantage and success (Armstrong, 2006). Boxall (1996) refers to this situation as one that confers "human capital advantage". Firms which recruit and retain exceptional individuals can create competitive advantage for themselves (Boxall, 1998). The competitive advantage which emanates from employee performance in part is a function of prudent human resource planning practice that enables an organization acquire qualified and competent human resources and facilitates deployment on the basis of the candidates ability-job fit.

\subsubsection{Human Resource Planning}

Nzuve (2011) explains that human resource planning is a formal function in the management of human resources which involves analysing an organization's human resource needs. It works towards helping an organization obtain the right number and kind of employees in the right places at the required time, and as such one of the key ingredients towards an organization's strength and growth. This stance resonates with the assertion of Waweru (2007) that man power planning (which is synonymous with human resource planning) will involve the determination of the number of employees required as well as the variety of skills that will be demanded of them. Cole (2009) views it as any rational and planned approach for ensuring the recruitment of sufficient and suitable staff, their retention in the organization, their optimum utilization, the improvement of their performance and their disengagement, if necessary. In this respect, HRP is concerned with both the quantity and quality of personnel and their deployment throughout the organization.

Beyond its operational identity, Torrington, Hall and Taylor (2008) identify four specific ways in which human resource planning is critical to strategy. They assert that HRP facilitates the identification of: gaps in capabilities, surpluses in capabilities, poor utilization of people and developing a talent pool. Armstrong (2006) suggests that HRP should be an integral part of business planning. He elaborates that the strategic planning process should define projected changes in the scale and types of activities carried out by the organization. According to him, HRP should identify the core competencies the organization needs to achieve its goals and therefore its skill requirements. In so far as there are articulated strategic business plans, he argues that human resource planning will interpret them in terms of people requirements.

While a number of models explain the process of human resource planning, the study adopted a model by Armstrong (2009) which identifies five activities that characterize HRP and uses them as the dimensions of HRP in the conceptual framework. These are: business plans and/or scenario planning, demand forecasting, supply forecasting, forecasting requirements and action planning. Initiating the HRP process are business plans which emanate from organizational plans such as expansion, diversification, shrinking etc. Embedded to the business plans is scenario planning which is an assessment of the environmental changes that are likely to affect the organization so that a prediction of the possible situations that may have to be dealt with in the future are made. It is based on systematic environmental scanning possibly using PEST approach. Following business / scenario planning is demand forecasting which helps estimate the future numbers of people required and the likely skills and competencies they will need. This is then preceded by supply forecasting which measures the number of people likely to be available from within and outside the organization, having allowed for absenteeism, internal movements and promotions, wastages and changes in hours and other conditions of work. The basis of the demand forecast is the annual budget and longer-term business plan, translated into activity levels for each function and department or decisions on "downsizing". The techniques that can be used to forecast demand requirements are manifold.

Forecast of future requirements, which is the next step, is necessary in analysing the demand and supply forecasts so as to identify any deficits or surpluses. Action plans derived from the broad resourcing strategies and the more detailed analysis of demand and supply factors are then identified. The planning activities start with the identification of internal resources available now or which could be made available through learning and development programmes. They continue with plans for increasing the attractiveness of working for the organization by developing an employer brand. Successful HRP identifies HR needs while recruitment marks the 
first step in meeting the needs.

\subsubsection{Lecturers' Performance}

Performance is a multi-dimensional construct (Dugguh \& Ayaga, 2014). Performance in organizational context is broad and has been a subject of study among social scientists from a wide range of disciplines, and that it can be used synonymously with productivity, efficiency, effectiveness and, more recently, competitiveness (Cooke, 2001). Performance incorporates behaviour and results, a position that the study adopted (Brumbach, 1998; Dugguh \& Ayaga, 2014). Behaviour emanates from performer and transforms performance from abstraction to action

Employee performance thus refers to the job-related activities expected of employees and how well they execute them (Dugguh and Ayaga, 2014). The study operationalized lecturers as employees of universities whose responsibility is to transform, develop and disseminate knowledge through education, research and community service. Consequently, their performance is primary to the success of a university. Lecturers' performance was, therefore, be conceptualized as the job related behaviours and results expected of lecturers (Brumbach, 1998; Dugguh and Ayaga, 2014).

Different sources propose different measures or indicators of lecturers' performance. To begin with, Molefe (2010) who defines a measure as a specific quantitative or qualitative representation of capacity, process or outcome deemed relevant to the assessment of performance suggests that lecturers' performance can be measured or indicated by subject knowledge, testing or assessment procedure, student-teacher relations, organizational skills, communication skills, subject relevance and utility of assignments. On the other hand, Sánchez-Barrioluengo (2013) in World Bank (2017) explains that the higher education community generally identifies three distinct but interrelated missions: teaching and learning, research and community engagement against which the performance of lecturers could be measured.

Abba and Mugizi (2018) summarize the performance of academic staff as being indicated by: teaching, research and publication, innovation and community service while Commission for University Education (2014a and 2014b) wrap lecturers' performance around four thematic areas: quality of teaching and learning; research and publication; administration and responsibilities and community engagement and other contributions. As a policy, the commission embedded the appointment and promotion of academic staff in public universities in the four areas through a document entitled "Harmonized Criteria and Guidelines for Appointment and Promotion of Academic Staff in Universities in Kenya". While the document was challenged in a court of law by University Academic Staff Union, the concern was only failure to involve the Union s a stakeholder and not the performance areas. Universities have, therefore, retained the performance areas with some variations on weighting. This study therefore, adapted the Commission for University Education's indicators, and blended them with relevant dimensions of measures proposed by other researchers in Molefe (2010) in light of the criteria used by different universities in Kenya. It is worth noting that all public universities have adapted the four thematic areas of lecturers' performance measurement as outlined in the two CUE documents.

According to Commission for University Education of Kenya (2014a and 2014b), quality of teaching and learning is measured by the following: student evaluation of the instructor and course; the lecturer's notes; ability to advise and mentor students; training in higher education teaching and post graduate supervision. Whereas student evaluation may court controversy, Balam and Shannon (2010); and Bedggood and Donovan (2012) submit that there is sufficient literature to conclude that they are generally consistent and valid (Arnold, 2008 and Liu, 2012). Related to these is a lecturer's knowledge-base in the subject as proposed by Analoui (2007) who views it as being fundamental to the creation and enhancement of the student's opportunity to learn well. The knowledge base encompasses declarative knowledge of facts and concepts, the procedural knowledge of what to do and the motivation which could include effort and persistence to excel (Aguinis, 2009). Ganyaupfu (2013) adds the teaching skills of a lecturer to this list. He explains that a lecturer's teaching skills is based on their ability to comprehend and transform concepts to be imparted to learners. The position is reinforced by Shulman (1992) who views comprehension as an important element of lecturer competence. Sinclear and Johnson (2000) assert that thorough knowledge of the subject material is essential to accurate instruction and clear communication and content to students. Arreola (2000) opines that the quality of teaching and learning should also include expertise in the content area.

In addition to content knowledge, ability to organize, integrate, adjust and adapt this content in ways that make it accessible and thought provoking to the learner are the other parameters of quality of teaching and learning (Gill and Johnson, 1997; White, 2008). Testing or assessment procedure which entails designing, developing and implementing tools and procedures for assessing students' learning outcomes and is part of the instructional 
design (Molefe, 2010) also contributes to the quality of teaching. Arreola (2000) identifies requisite skills under this dimension as: designing tests; preparing the learning objectives; developing syllabi; preparing handouts and other supporting materials; properly using media and other forms of instructional technology and organizing lectures and presentations for maximal instruction. Hill, Lomus and MacGregor (2003) add feedback to students during the sessions and assignments to this list.

Molefe (2010) further points out the importance of student-teacher relations in teaching and learning. He relates it to the creation and maintenance of student-centred environment that maintains and sustains learning and development. According to him, it is a dimension that is integral to high learner-performance. Arreola (2000) asserts that a teacher who can develop relationships that foster and encourage students will enhance learning. Encouragement of active participation in the classroom creates a supportive environment where questions and class discussions are promoted, which imbues the lecturer with enthusiasm for the subject and facilitates opportunities for generating regular informal feedback on students as well as deeper understanding of the subject matter (Sinclair and Johnson, 2000).

Sinclair and Johnson (2000) opine that organizing skills is another dimension that influences overall student experiences, as well as the quality of teaching. Included herein is also the bureaucratic skills utilised for operating and managing a course including, but not limited to, timely grading of examinations, maintaining published office hours, arranging for and coordinating guest lecturers and generally making arrangements for facilities and resources required in the teaching of the course. In support of this stance is Arreola (2000) who asserts that excellent teachers do their work in a well-prepared and well-organized manner by arranging their activities in a way that allows them time to engage in corporate citizenship and community outreach. It is worth noting that corporate citizenship and community outreach are other measures of lecturer performance according to the Commission for University Education (2014a and 2014b).

Molefe (2010) further identifies communication as an important aspect of structural delivery skills that enhances teaching and learning. Clarity in exposition, demonstrated enthusiasm, ability to motivate, ability to capture and hold the interest and attention of learners and create an overall learning environment appropriate to the content being taught are all included in communications skill dimension (Arreola, 2000). According to Hill et al., 2003 and White, 2008, subject relevance is another factor that concerns learning and teaching quality. It relates to the appropriateness of the content provided during the lesson and the way in which it is presented to the learners. They suggest that it should entail accuracy of the facts encapsulated in the course content. Relevant assessment instruments used in the course should add to the design of architecture within the frame of reference of the course materials and the real world associated with the subject. Questions should be set at the appropriate level and graded according to the learning outcomes of the module. The text books and reference materials recommended by the lecturers, as well as the appropriate use of methods and techniques used in the subject are also of vital importance. The course being offered should also be of value to the workplace.

Towards enhancing the quality of teaching and learning, White (2008) opines that the assignments given to students should be meaningful and ones that enhance their learning and developmental needs. The assignments should be within the frame of reference of the course materials and the real world associated with the subject and socio-economic life within which a student lives. To further enhance utility, Layman, Williams and Staten (2007) suggest that the assignment should reflect its learning objectives and make it interesting and challenging to the student.

Research and publication as an indicator of lecturer performance generally implies the ability to advance scholarship and generate research as advanced by Gill and Johnson (1997) and White (2008). Implicit in the generation of research is the advancement of knowledge through discovery, integration, dissemination and application of knowledge. Commission for University Education (2014b) suggests that it entails: publication of scholarly books and chapters in books; refereed journals; refereed learning modules; reviewed conference papers; non-reviewed conference papers; short communication in a refereed / scholarly journals; book reviews published in refereed journals; editorship of books and conference proceedings; scholarly presentations at conferences, workshops or seminars; refereed exhibitions and performances; consultancy and project reports; and patented invention and innovation. While these measures advance a quantitative component (i.e. numbers of), Harvey et al. (2010); Long et al. (2009) and Stack (2003) in Cadez, Dimovski and Groff (2017) suggest that the quality aspect be interrogated via the impact and quantity of papers published in an exclusive set of high quality journals or by the number of citations.

Administration and Responsibilities as a measure of lecturer performance encapsulates recognized university administrative positions and any other reponsiblilties that may be assigned to a lecturer. Community engagement 
and other Contributions, on the other hand, is rated by the ability of a lecturer to attract research and development funding; engagement in community service and outreach, professional affiliations and portfolios, recognition, awards and honours amongst others as determined by individual Universities (Commission for University Education, 2014b).

\subsection{Review of Empirical Literature}

\subsubsection{Human Resource Planning Practice and Lecturers' Performance}

All the reviewed studies examined aspects of HRP, although with variations. Mbiu and Nzulwa (2018) focused on recruitment and deployment; training and orientation; talent retention; and succession planning as the descriptors of HRP consequently ignoring business plans and scenario planning; demand forecasting; supply forecasting; and forecasting of future requirements and action planning which are the activities that mark HRP process (Armstrong, 2009). Similarly, Karia, Omari, Mwanaongoro and Ondieki (2016) examined HRP in light of participation of employees; implementation of HRP; and management support while Maina and Kwasira (2015), focused on components of HRP such as employee attraction and retention. Whereas Anya, Umoh and Worlu (2017) operationalized HRP to include strategic action and forecasting manpower demand which comprise some of the aspects of HRP identified by Armstrong (2009), they apparently ignored business plans and scenario planning; supply forecasting; and forecasting future requirements. Ogunyomi and Ojikutu (2014), on the other hand, broadly studied employee resourcing that they operationalized to include HRP, recruitment and selection and employee retention in a similar way to Katua, Mukulu and Gachunga (2014) who also broadly considered employee resourcing strategies as incorporating recruitment, selection, induction and HRP. Kamande and Gachunga (2014) used employee resourcing, career planning, succession planning and human resource development as descriptors of HRP. Abdulla, Ahsan and Alam (2009) studied HRP in its composite as a facet of HRM practice while Anyadike (2013) did not specify its descriptors. Therefore, none of the studies strictly used all the five facets of HRP in entirety as proposed by Armstrong (2009) like in the current study.

Anya, Umoh and Worlu (2017), Karia, Omari, Mwanaongoro and Ondieki (2016), Ogunyomi and Ojikutu (2014), Katua, Mukulu and Gachunga (2014), Kamande and Gachunga (2014) and Abdula, Ahsan and Alam (2009) related various aspects of HRP to organizational performance contrary to Maina and Kwasira, (2015) who related certain proxies of HRP to employee performance. Mbiu and Nzulwa (2018) and Anyadike (2013), on the other hand, relate aspects of HRP to employee productivity. Productivity is equated to performance (Cook, 2007). Therefore, employee productivity implies employee performance in this context. Much as Maina and Kwasira, (2015); Mbiu and Nzulwa (2018) and Anyadike (2013) studied HRP in relation to employee performance or productivity, its descriptors such as business plans and scenario planning, demand forecasting, supply forecasting, forecasting future requirements and action planning (Armstrong, 2009) were not studied. Furthermore, Anyadike (2013) who studied HRP in relation to employee performance relied on document analysis without empirical evidence which diminishes confidence in his conclusions. In addition, while both Mbiu and Nzulwa (2018) and Maina and Kwasira (2015) conducted their studies in the context of employees of county governments, the former limited their study to only 55 respondents based in Nairobi while the latter to only 45 human resource experts in a single department (Human Resource Department). Consequently, the study by Mbiu and Nzulwa (2018) is not sufficiently robust considering the limited population. Similarly, Maina and Kwasira (2015) also deny their study diversity in expertise and job categories and, as a result, their findings cannot be appropriate for generalization in a diverse population. Lecturers, as in the current study, present a diverse range of expertise and cadre within the University setting. The larger sample (158) and diversity in the choice of the sampled universities enhance confidence and generalizability of the findings.

In light of the influence of HRP on lecturers' performance in Kenyan public universities, the reviewed literature, revealed gaps that the current study sought to fill. Whereas a majority of the studies (Mbiu \& Nzulwa, 2018; Anya, Umoh \& Worlu, 2017; Karia, Omari, Mwanaongoro \& Ondieki, 2016; Maina \& Kwasira, 2015; Katua, Mukulu \& Gachunga, 2014; Kamande \& Gachunga, 2014; Anyadike, 2013; Abdulla, Ahsan \& Alam, 2009) established a positive significant relationship between HRP and either employee or organizational performance, Ogunyomi and Ojikutu (2014) found that HRP is a non-predictor of the performance of SMEs. These studies, therefore, gave mixed results. While Anya, Umoh, and Worlu (2017); Karia, Omari, Mwanaongoro and Ondieki (2016); Ogunyomi and Ojikutu (2014); Katua, Mukulu and Gachunga (2014); Kamande and Gachunga (2014); Abdulla, Ahsan and Alam (2009) related HRP to organizational performance, the three studies that related it to employee performance (Mbiu \& Nzulwa, 2018; Maina \& Kwasira, 2015; Anyadike, 2013) ignored the facets of HRP such as business plans and scenario planning; demand forecasting; supply forecasting; forecasting future requirements and action planning which are the key activities in HRP (Armstrong, 2009). Moreover, Anyadike (2013) relied on document analysis purely which compromises confidence in his conclusions. Similarly, Mbiu 
and Nzulwa (2018) and Maina and Kwasira (2015) used limited samples that are not sufficiently robust for effective generalization. Maina and Kwasira (2015) deny their study diversity in expertise and job categories and, as a result, their findings are not appropriate for generalization in a diverse population.

\section{Research Methodology}

\subsection{Research Design}

Kothari (2004) defines research design as the arrangements of the conditions for collection and analysis of data in a manner that aims to combine relevance to the research purpose with economy in procedure. Descriptive cross-sectional survey research design was used in the collection and analysis of data. Rubin and Babbie (2001) define a survey research design as scientific method of inquiry in which the researcher selects a sample of respondents and administers a standardized research instrument on them. Descriptive research studies, according to Kothari and Garg (2014), describe the characteristics of a particular individual, or of a group. They facilitate predictions, with narration of facts and characteristics concerning individuals, groups or situations. Creswell (2009) observes that surveys as forms of quantitative strategies can provide quantitative or numeric description of trends, attitudes, or opinions of a population by studying a sample of that population. The study used individuals (AHoDs) as the unit of analysis. Cross-sectional survey was preferred because it facilitated the collection of data from various cases at the same time hence a variety of views over the same issue captured in a short time. The correlational approach assisted in establishing whether there existed a significant association between the independent, moderator and the dependent variables (Mugenda, 2008; Kothari and Garg, 2014). Creswell (2009) opines that questionnaires can be used to collect data in cross-sectional study.

\subsection{Study Area}

The study focused on fourteen (14) chartered public universities that were established between 2009 and 2019 , but spread across the Republic of Kenya. Kenya lies between Latitude: $0^{\circ} 10^{\prime} 36.73$ " N and Longitude: $37^{\circ} 54^{\prime}$ 29.98" E, and on the equator with the Indian Ocean to the South-East, Tanzania to the South, Uganda to the West, South Sudan to the North-West, Ethiopia to the North and Somalia to the North-East. The country was targeted due to the misgivings that Higher Education stakeholders have expressed regarding the quality of education in her universities (Mwiria and Nyukuri, 1994; Ngolovoi, 2006; Wangenge-Ouma, 2007; Gudo, Olel and Oanda (2011); Kaburu (2014) and Ayiro (2015).

\subsection{Target Population}

Asiamah, Oteng-Abayie and Mensah (2017) identify three concepts that are related to research population, but are otherwise often misunderstood: general, target and accessible population. They do not only argue for a researcher's sufficient understanding of the study population, but also a clear definition of the same at the stage of documenting the research. They view the general population as the largest group of potential participants of a study in accordance with Barnejee and Chaudhury's (2010) definition that it comprises the entire group about which some information is required to be ascertained. Umar (2018) views target population as the population of interest in a given study. It is thus the theoretical population. According to Bartlett et al. (2001), target population is the group of individuals or participants with specific attributes of interest and relevance. It is, therefore, the part of general population that is left after refinement that eliminates all individuals whose involvement in the study would breach the research goal, assumptions or context. As such, the target population of the current study comprised all the 1,653 lecturers in the fourteen (14) chartered public universities established between 2009 and 2019. The study, therefore, excluded any lecturer outside this specification.

Accessible population is arrived at after eliminating all individuals who may not participate or who cannot be accessed in the course of the study (Bartlett et al., 2001). It constitutes the final group from which data is collected in whole or as a sample. It, therefore, represents the sampling frame. Accordingly, the accessible population of the current study comprised all the 178 AHoDs/ Deans/Directors of schools or faculties in the 14 Chartered Kenyan public universities established between 2009 and 2019.

\subsection{Sample Design and Size}

Kothari (2004) defines sample design as a definite plan for obtaining a sample from a given population. It refers to the technique or procedure that the researcher adopts in selecting items for a sample. He observes that it may as well lay down the number of items to be included in the sample (i.e. sample size). The study adopted multistage purposeful sampling technique in which the study sample was selected in two stages purposively (Omona, 2013; Onwuegbizie and Leech, 2007). In the first stage, the study purposively focused on 1,653 lecturers in the 14 chartered public universities established between 2009 and 2019 (its target population), from 
the general / entire population of 8,737 lecturers in the 31 chartered public universities in Kenya as at $20^{\text {th }}$ October, 2019. The universities were selected on the basis of the staffing challenges they are faced with (Ikama, 2010: Kagondu and Marwa, 2017) and the pressure exerted on them to employ (Mukhwana et al., 2016).

Judgement sampling was then purposively employed, in the second stage, to take a census of all the academic heads of departments (AHoDs) totalling to 178 in the 14 chartered public universities. The choice of AHoDs was informed by their participation in HRP decisions and buttressed by virtue of them being the immediate supervisors of the lecturers thus better placed to monitor and assess their performance. Their choice was further qualified by the fact that they are representative of all the categories of lecturers considering that they are drawn from disparate ages, gender, academic positions or ranks and qualifications across the universities apart from being lecturers themselves. The deans and directors of schools and institutes that were not established as departments under existing schools or faculties were considered the AHoDs. Given their limited number, a census of 158 AHoDs was used after conducting a pilot study on 20 AHoDs from Jaramogi Oginga Odinga University of Science and Technology (JOOUST). From the population of 14 universities, JOOUST was selected using simple random sampling technique. Monette, Sullivan and Dejong (2002) suggest that a sample of 20 respondents is sufficient for pilot testing in a survey.

Table 1: Multistage Purposeful Sampling Procedure

\begin{tabular}{|c|c|c|c|c|}
\hline Stage & No. of Universities & Total No. of Lecturers & Population Type & Sampling Technique \\
\hline & $\begin{array}{l}31 \text { Chartered Kenyan Public } \\
\text { Universities. }\end{array}$ & 8,737 & $\begin{array}{l}\text { General/Study } \\
\text { Population }\end{array}$ & $\begin{array}{l}\text { Entire population of } \\
\text { lectures }\end{array}$ \\
\hline 1. & $\begin{array}{l}14 \text { Chartered Kenyan Public } \\
\text { Universities established between } \\
2009 \text { and } 2019 .\end{array}$ & 1,653 & Target Population & Purposive Sampling \\
\hline 2. & $\begin{array}{l}14 \text { Chartered Kenyan Public } \\
\text { Universities established between } \\
2009 \text { and } 2019 .\end{array}$ & $\begin{array}{l}178 \\
(\mathrm{~A} \quad \text { census of } \\
\text { AHoDs/Deans/Directors) }\end{array}$ & Accessible Population & $\begin{array}{l}\text { Purposive and } \\
\text { Judgement Sampling }\end{array}$ \\
\hline
\end{tabular}

Source: Preliminary Survey, 2019

\subsection{Data Collection Methods}

\subsubsection{Data Type and Sources}

Both primary and secondary data were collected in the context of this study. Primary data was collected from the respective AHoDs using semi-structured questionnaires while secondary data extracted from journal articles, human resource records, audit reports, relevant books and institutional websites. Cooper and Schindler (2008) merit primary data for their proximity to the truth and control over error.

\subsubsection{Data Collection Procedures}

Prior to the administration of the data collection instrument, the researcher first obtained authorization to collect data from the School of Graduate Studies, Maseno University; Maseno University Ethical Review Committee; and research permit from National Commission for Science, Technology and Innovation Permission to collect data was then sought and obtained from the administration of the respective universities that comprised the study. This was followed by an informal familiarization visit to the targeted universities to create rapport and locate the relevant offices, and respondents. It is at this point that the researcher obtained tentative dates and time for the administration of the questionnaires at the convenience of the respondents.

The research questionnaire had hitherto been given to a panel of seven experts, in consultation with the researcher's supervisors, for review. Having incorporated their suggestions which included summarizing the items that were considered wordy, use of common words, reconstruction of poorly constructed item and blending of negative and positive statements in the questionnaire items, it was then piloted on twenty (20) AHoDs drawn from Jaramogi Oginga Odinga University of Science and Technology and their suggestions incorporated too. Monette, Sullivan and Dejong (2002) suggest that a sample of 20 respondents is sufficient for pilot testing in a survey.

Accordingly, the questionnaire items were adjusted for reliability and validity based on the pilot results and the AHoDs suggestions. All the proposals that were advanced by the AHoDs were considered. They included shortening of the questionnaire by omitting redundant and overlapping items, simplifying items, summarizing items that appeared verbose; reconstructing poorly constructed items and elimination of ambiguities. Pilot study, 
according to Orodho (2005), helps determine both the validity and reliability of the research instruments. The AHoDs used in piloting were ultimately excluded from the main study.

\subsubsection{Data Collection Instruments}

Kothari and Garg (2014) describe the questionnaire as the heart of a survey operation. Consequently, semistructured questionnaire was used to collect data from the AHoDs. The questionnaire was divided into three parts as follows: Part A collected data on the demographic profiles of respondents and departments, Part B collected data on human resource planning practices and part $\mathrm{C}$ data on lecturers' performance.

\subsubsection{Reliability and Validity Tests}

The study employed Cronbach's alpha coefficient analysis (with the aid of Statistical Package for Social Sciences (SPSS) software) to examine the internal consistency of the measures since it is the most reliable test of inter-item consistency reliability for Likert scaled or rating scaled measures (Whitley, 2002 \& Robinson, 2009). The instrument had adequate reliability for the study with all the items hanging out well with others in all the sub-scales. They were all within the acceptable range of 0.70 to 0.9 , as recommended by Tavakol and Dennick (2011) and George and Mallery (2003). In addition, with an overall scale reliability of 0.796 and a standard deviation of 0.067 , the instrument was of an acceptable reliability standard. to ascertain content validity, literature search was conducted to ensure that the items in the questionnaire were within the domain of the study concepts as defined by the researcher (Kimberlin \& Winterstein, 2008; Drost, 2011) and corroborated by a panel of experts (Cooper and Schindler, 2008; Drost, 2011; Aila \& Ombok, 2015). Construct validity, on the other hand, was conducted using Pearson Product Moment Correlations with the aid of SPSS version 21.0. Based on the significant values obtained by the Sig. (2-tailed) $<.05$, it was evident that all items in each sub-scale significantly correlated with their sub-scale totals, except for item 4 in the forecasting future requirements and action planning sub-scale. The item was excluded from the final analysis of the data given that it had failed the validity test. Generally, the questionnaire items were of adequate validity since they significantly correlated with their total sub-scales.

\subsubsection{Data Analysis}

The collected data were processed and organized for statistical analysis. Both descriptive and inferential statistics were used. Pearson's $r$ was used to determine the magnitude and direction of relationship between variables (Cooper and Schindler, 2008) while multiple regression used to predict the influence of human resource planning on lecturers' performance. All tests of significance were computed at $\alpha=0.05$. The Statistical Package for Social Sciences (SPSS) version 21.0 aided data analysis.

\subsubsection{Model Specification}

The study sought to establish the influence of human resource planning practice on lecturers' performance in Kenyan public universities. This objective was investigated by testing the null hypothesis that: human resource planning practice has no influence on lecturers' performance in Kenyan public universities. Human resource planning practice was measured using four sub-scales, namely: business plans and scenario planning; demand forecasting; supply forecasting; and forecasting future requirements and action planning. The data for each of the four sub-scales was collected using a 5-point Likert scaled questionnaire. The Likert scale responses were then converted in continuous scale data by computing the mean response in each item. Accordingly, the multiple regression model that follows in Equation 1 was used to explore the hypothetical influence of the various aspects of human resource planning practice on lecturers' performance in Kenyan public universities. The model was adapted from Cooper and Schindler (2008).

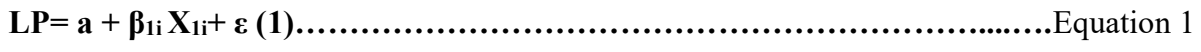

Where:

LP

$\mathrm{X}_{\mathrm{i}(\mathrm{i}=1,2,3,4)}$

$\mathrm{X}_{1}$

$\mathrm{X}_{2}$

$\mathrm{X}_{3}$

$\mathrm{X}_{4}$

$\varepsilon$
$=$ Lecturers' Performance

$=$ Human resource planning practices in which:

$=$ Business Plans and Scenario Planning,

$=$ Demand Forecasting,

$=$ Supply Forecasting

=Forecasting Future Requirements \& Action Planning

$=$ Error term 


\section{Assumptions of Regression Analysis}

According to Osborne and Waters (2002), most statistical tests rely upon certain assumptions about the variables used in the analysis. In line with the recommendation of Field (2013), diagnostic tests were done to ascertain the suitability of the collected data for multiple regression analysis. Test for normality employed Shapiro-Wilk's test (S-W), in line with the recommendation of Thode (2002); Gravetter \& Wallnau (2000); Oso and Onen (2013) and Zar (1999); Durbin Watson to examine independence of errors at a range of $1.50-2.50$ as proposed by Tabachnick and Fidell (2001) and Keppel \& Zedeck (1989). Tolerance and variance inflationary factor (VIF) were used to investigate the assumption of multicollinearity (O'Brien, 2007); homoscedasticity and heteroscedasticity employed the use of scatter plot; independence of errors was examined through DurbinWatson (Kothari and Garg, 2014; Fox, 1991).

\section{Results}

\subsection{Descriptive Statistics on Lecturers' Performance}

Generally, lecturers' performance was summarized in four sub-scales which the researcher used as its dimensions. The sub-scales were: quality of teaching and learning, research and publication, administration and responsibilities, and community engagement and other contributions. Table 2 indicates the summary of lecturer's performance ratings in means and standard deviation.

From Table 2, it is evident that the overall lecturer's performance in Kenyan public universities was above average. Using the scale of 1 to 5 , the study established an overall rating of $4.01(\mathrm{SD}=0.62)$ indicating a fairly strong level of performance among the lecturers. Quality of teaching, as a dimension of performance, had the highest rating at 4.27 with a standard deviation of 0.53 , implying that lecturers performed best in Teaching and Learning compared to other dimensions of performance. This was closely followed by Administration and Responsibilities at 4.22 with a standard deviation of 0.54 . Research and Publication came third with a mean rating of $3.82(\mathrm{SD}=0.65)$ while Community Engagement and Other Contributions came last with mean rating of $3.75(\mathrm{SD}=0.76)$ respectively. Considering the above average means in all the dimensions, Kenyan university lecturers generally performed well in discharging their duties. The findings support those of Kara, Tanui and Kalai (2020) who established that a majority of lecturers in Kenyan public universities had the desired professional quality and engaged in quality instructional practices.

Table 2: Summary of Sub-Scales of Lecturers Performance

\begin{tabular}{lll}
\hline Sub-Scales in Lecturers Performance & Mean & SD \\
\hline Quality of Teaching and Learning & 4.27 & 0.53 \\
Research and Publication & 3.82 & 0.65 \\
Administration and Responsibilities & 4.22 & 0.54 \\
Community Engagement and Other Contributions & 3.75 & 0.76 \\
\hline Overall Mean Rating & 4.01 & 0.62 \\
\hline
\end{tabular}

Source: Survey data (2020)

\subsection{Descriptive Statistics on Human Resource Planning Practice}

The four sub-scales of human resource planning practice were summarized using means and standard deviations. The findings are presented in Table 3. 
Table 3: Summary of Human Resource Planning Practice

\begin{tabular}{lcc}
\hline Sub-scales/Dimensions of HRP Practice & Mean & $\begin{array}{c}\text { Standard } \\
\text { Deviation }\end{array}$ \\
\hline Business Plans and Scenario Planning & 3.52 & 0.87 \\
Demand Forecasting & 3.36 & 0.92 \\
Supply Forecasting & 2.99 & 0.98 \\
Forecasting Future Requirements and Action Planning & 2.96 & 1.02 \\
\hline Overall Mean rating of Human Resource Planning Practice & 3.21 & 0.76 \\
\hline
\end{tabular}

Source: Survey data (2020)

From Table 3, it is evident that public universities in Kenya, in general, have above average rating in their human resource planning practices. This was reflected by an overall mean rating of 3.21 with a standard deviation of 0.76 in a scale of 1 to 5 . This suggests that, on average, administrations of public universities in Kenya have more than average abilities in identifying current and future lecturers' needs for their universities. The sub-scale of Business Plans and Scenario Planning received the highest rating (Mean=3.52; $S D=0.87)$. This implies that the universities, on average, did not employ haphazardly but on the basis of organizational plans and possible scenarios. It was followed by Demand Forecasting which received a mean rating of 3.36 ( $S D=0.92)$, reflecting that the management of public universities are fairly effective in estimating the future quantity and quality of the lecturers required. Supply Forecasting, and Forecasting Future Requirements and Action Planning received almost similar rating at $2.99(\mathrm{SD}=0.98)$ and $2.96(\mathrm{SD}=1.02)$, respectively. This suggests that public universities project the possible sources of employees they hire before matching demand and supply to reveal employee surpluses and deficits. On the basis of the surpluses or deficits, the organizations decide on the remedial action to adopt. However, the performance of public universities in these two dimensions requires more reinforcement given the respective means that are barely above average.

\subsection{Relationship between Human Resource Planning Practice and Lecturers' Performance in Kenyan Public Universities}

The study investigated the relationship between human resource planning practice and lecturers' performance. The investigation was done using Pearson Product Moment Correlation analysis to establish the magnitude and direction of the relationships between the individual aspects of human resource planning practices and lecturers' performance. The means of each aspect of human resource planning practice as well as that of the overall human resource planning practice were correlated with lecturers' performance. The significance value was set at 0.05 ; implying that a p-value less than 0.05 would lead to conclusion that there is statistically significant relationship between the variables, while p-value greater than 0.05 would lead to conclusion that the correlation is not statistically significant. The correlation results are summarized in Table 4

Table 4 Correlation of Human Resource Planning and Lecturers' Performance

\begin{tabular}{lccc}
\hline & $\mathrm{n}$ & $r$ & $p$-value \\
\hline Business plans and scenario planning & 136 & .028 & .075 \\
Demand forecasting & 136 & .538 & .000 \\
Supply forecasting & 136 & .054 & .053 \\
Forecasting future requirements and action planning & 136 & .428 & .000 \\
\hline Overall rating of Human Resource Planning Practice & 136 & .528 & .000 \\
\hline
\end{tabular}

\section{Source: Survey data (2020)}

It is evident that although the four aspects of human resource planning practices exhibited positive correlation with lecturers' performance, the magnitude of correlations varied and some were not statistically significant. For instance, Demand Forecasting recorded the strongest correlations at $r=.538 p=.000$, followed by the indicator Forecasting Future Requirements and Action Planning at $r=.428, p=.000$ with both the two indicators having statistically significant relationship to Lecturers' Performance. On the other hand, whereas both Business Plans and Scenario Planning $(r=.028, p=.075)$, and Supply Forecasting $(r=.054, p=.053)$ had some positive correlation to Lecturers' Performance, their correlations were not statistically significant. 
Nonetheless, overall Human Resource Planning Practice had statistically significant positive correlation $(r=.528$, $p=.000)$ to Lecturers' Performance in Kenyan public universities. This implies that Human Resource Planning Practice has a moderate positive correlation with Lecturers' Performance. Thus, an improvement in Human Resource Planning Practice raises the level of lecturers' performance and vice versa. The findings of the study are consistent with those of Maina and Kwasira (2015) and Mbiu and Nzulwa (2018) much as they restricted themselves to employee attraction and retention on the one hand; and recruitment and deployment, training and development of talent, talent retention and succession planning on the other hand as descriptors of Human resource planning practice.

The research data was further subjected to multiple regression analysis (Table 5) to establish the influence of Human Resource Planning Practice on Lecturers' Performances in Kenyan public universities.

5.4 The Influence of Human Resource Planning Practice on Lecturers' Performance Public Universities in Kenyan

To establish the influence of human resource planning practice on lecturers' performance in Kenyan public universities, the null hypothesis that "human resource planning practice has no influence on lecturers" performance in Kenyan public universities" was tested. Human resource planning practice was measured using four dimensions namely: Business Plans and Scenario Planning, Demand Forecasting, Supply Forecasting, and Forecasting Future Requirements \& Action Planning. Mean response across a set of Likert-type scale responses in each item was computed to create an approximately continuous variable within an open interval of 1 to 5 as determined to be suitable for the use parametric data by Johnson and Creech (1983) and Sullivan and Artino (2013). High scale rating was interpreted to imply a corresponding high implementation of human resource planning practice that would influence lecturers' performance.

The study adopted multiple regression analysis with the investigated null hypothesis being $\mathrm{H}_{0}$ : $\beta_{1}=\beta_{2}=\beta_{3}=\beta_{4}=0$ and the corresponding alternative hypothesis being $\mathrm{H}_{1}$ : at least one $\beta_{\mathrm{i} \neq} 0$. If the null hypothesis is true, then from $E(Y)=\beta_{0}+\beta_{i=1,2,3,4} X_{i=1,2,3,4}$ the population mean of $Y$ is $\beta_{i}$ for every $X_{i}$ value which indicates that $X$ (human resource planning practice) has no influence on Y (lecturers' performance) in Kenyan public universities, and the alternative being that $\mathrm{X}$ (human resource planning practice) influences $\mathrm{Y}$ (lecturers' performance) in Kenyan public universities. The priori significance level was set at 0.05 , such that if the p-value was less than 0.05 then the null hypothesis would be rejected and a conclusion reached that a significant difference exists. On the other hand, if the p-value was greater than 0.05 , then it would be concluded that a significant difference does not exist. Table 5 shows the results of the regression model summary.

Table 5 Regression Model on Influence of Human Resource Planning Practice on Lecturers' Performance

\begin{tabular}{lrrrrrrr}
\hline Variable & B & SE & Beta & t & Sig. & 95\% CI & $\begin{array}{r}\text { Part } \\
\text { Correlation }\end{array}$ \\
\hline Constant & 0.825 & 0.42 & & 1.962 & 0.052 & $(-0.007,1.656)$ & \\
Business plans and scenario planning & -0.009 & 0.08 & -0.008 & -0.114 & 0.909 & $(-0.168,0.150)$ & -0.008 \\
$\begin{array}{l}\text { Demand forecasting } \\
\text { Supply forecasting }\end{array}$ & 0.538 & 0.08 & 0.474 & 6.691 & 0.000 & $(0.379,0.697)$ & 0.454 \\
$\begin{array}{l}\text { Forecasting future requirements } \\
\text { action planning }\end{array}$ & 0.021 & 0.061 & 0.023 & 0.338 & 0.736 & $(-0.100,0.141)$ & 0.023 \\
\hline
\end{tabular}

$R=.631$, Adjusted $R$ Square $=.380(S E=.4863), F=21.650, p=.000, \mathrm{df}\left(\mathrm{df}_{1}=4, \mathrm{df}_{2}=131\right)$

The model reveals that Human Resource Planning Practice, as measured by the four sub-scales, accounted for $38.0 \%$ (Adjusted $R^{2}=.380$ ) of the variation in Lecturers' Performance in the Kenyan public universities. This implies that $38.0 \%$ of variation in the performance of lecturers in Kenyan public universities is explained by the composite change of the four dimensions of Human Resource Planning Practice. Furthermore, the four dimensions revealed a fairly strong joint correlation $(R=.631)$ with lecturers' performance. It is, therefore, evident that Human Resource Planning Practice, as measured by the four dimensions, is indeed a significant predictor of lecturers' performance in Kenyan public universities, $F(4,131)=21.650, p=.000<.05$. The fairly low value of $F$ suggests that the variability within each of the variables was generally smaller than variation between the variables. This means that the knowledge on the level of each dimension of Human Resource Planning Practice in Kenyan public universities can be used to significantly predict Lecturers' Performance therein. 
The analysis further reveals that the four dimensions of Human Resource Planning Practice had varying influence on Lecturer's Performance. For instance, whereas two of the dimensions had significant positive unstandardized coefficients, some other two had insignificant un-standardized coefficients. On the one hand, Demand Forecasting dimension had a un-standardized coefficient value of 0.538 within a $95 \%$ C.I $(0.379,0.697)$ while Forecasting Future Requirements and Action Planning dimension had a un-standardized coefficient value of 0.299 within a $95 \%$ C.I $(0.173,0.425)$, which were all significant. On the other hand, the coefficients values for Business Plans and Scenario Planning dimension $(B=-0.009 ; t=-0.114, p=0.909)$ while Supply Forecasting dimension $(B=0.021 ; t=0.338, p=0.736)$ were not significant. However, given that two of the dimensions had significant un-standardized co-efficient values, there is sufficient evidence to reject the null hypothesis $\left(\mathrm{H}_{0}\right.$ : $\beta_{1}=\beta_{2}=\beta_{3}=\beta_{4}=0$ ). Hence, the alternative hypothesis was supported with the conclusion that human resource planning practices has statistically significant influence on lecturers' performance in Kenyan public universities.

More specifically, Demand Forecasting dimension had the greatest influence on Lecturers' Performance. A unit improvement in Demand Forecasting would result in improvement in lecturers' performance by .538 units. Similarly, when the university administration improves in Demand Forecasting by one standard deviation, the level of lecturers' performance would improve by .474 standard deviations. The second dimension in terms of influence was Forecasting Future Requirements and Action Planning which had an un-standardized value of .299 within a 95\% CI $(.173, .425)$. This implies that for one unit improvement in Forecasting Future Requirements and Action Planning dimension, there is a corresponding improvement in lecturers' performance in Kenyan public universities by .299 units, when other factors are held constant. Similarly, one standard deviation improvement in Forecasting Future Requirements and Action Planning results in a corresponding improvement in lecturers' performance by .333 standard deviations. Lecturers' performance in Kenyan public universities can, therefore, be improved by enhancing forecasts of future requirements and planning prudent intervening actions.

Business Plans and Scenario Planning dimension reflected the least effect on lecturers' performance in Kenyan public universities. A unit increase in Business Plans and Scenario Planning would result in a decrease in lecturers' performance by -.009 units which is negligible. Conversely, improvement in Supply Forecasting dimension by one unit would translate into an improvement in lecturer's performance by .021 units. The effects of both Business Plans and scenario Planning, and Supply Forecasting dimensions were not statistically significant $(p>.05)$ in the regression model.

Equally important is the part correlation coefficients, which indicates the contribution of each aspect of Human Resource Planning Practice to the total R squared. For instance, the results demonstrate that Demand Forecasting has a part correlation coefficient of .454, Forecasting Future Requirements and Action Planning of .319, Supply Forecasting of .023 and Business Plans and Scenario Planning of -.008. Squaring these values indicates how much of the total variance in the lecturers' performance in the Kenyan public universities is uniquely explained by the variable and how much $R$ squared would drop if it wasn't included in the model. Demand Forecasting which has the largest contribution to the model uniquely explains $20.6 \%$ of the variance in lecturers' performance in the Kenyan public universities and Forecasting Future Requirements and Action Planning uniquely explains $10.2 \%$ of variance. However, Supply Forecasting, and Business Plans and Scenario Planning only accounted for a negligible amount $(<1 \%)$ of the variance in lecturers' performance in Kenyan public universities. It is noteworthy that total $R$ Squared value for the model ( 0.380 or 38 per cent explained variance) was not equal to all the squared part correlation values added up because overlaps or shared variance were removed. Nonetheless, it was concluded that human resource planning practice regression model was adequate in predicting lecturers' performance in Kenyan public universities. The model was statistically significant at $F(4$, $131)=21.650, p=.000<.05$, accounting for $38.0 \%$ (Adjusted $R^{2}=.380$ ) of the variation in lecturers' performance in Kenyan public universities.

These findings concur with many theoretical arguments, especially the Decision Making Theory, in addition to the findings of many empirical studies. Nzuve (2010) points to the importance of HRP in helping management in decision-making in such areas as: recruitment, training and development, promotions, pay structures, retirement and pension schemes, industrial relations, and labour turnover - all of which have a theoretical relationship with employee performance. Farnham (2006) explains that apart from HRP encouraging employers to develop clear and explicit links between their business and HR plans and integrating the two effectively, it also to enables employers to make more informed judgements about the skills and attitude mix in organizations hence prudent deployment of employees.

Armstrong (2009) posits that linking of HR plans to corporate or business planning not only interprets these plans in terms of people requirements, but may also influence the business strategy by drawing attention to ways in which people could be developed and deployed more effectively to enhance the achievement of business goals 
as well as focusing on problems that might have to be resolved to ensure that the people required will be available and will be capable of making the necessary contributions. Generally, prudent decisions on the skills and attitude mix enhance prudent recruitment, training and development, deployment, resourcing and retention strategies thus enhanced employee and corporate performance.

Decision Making Theory which draws its significance from the role of decision making in the areas of recruitment, strategies to be adopted in recruitment and retention of employees for performance (Gberevie, 2010) is premised on the fact that decision-making is at the very heart of business success in any organization (Gberevie, 2006). Tonwe (1994) views the Decision-making Theory as assuming that the whole concept and purpose of organizations revolve around decision making. According to decision-making theorists, decisions are the selection of a proposed course of action (Butler, 1992; Iyayi, 2002). HRP practices entail management decision making in such areas as business plans and scenario planning, demand and supply forecasting, forecasting future requirements, and action planning.

Empirically, the findings of the study concur with those of Mbiu and Nzulwa (2018) who established a positive statistically significant relationship between human resource planning and employee productivity in County Governments in Kenya. However, unlike in the current study, human resource planning incorporated recruitment and deployment, training and orientation, talent retention, and succession planning as its descriptors. Similarly, Chege and Nasieku (2018) discovered a positive statistically significant relationship between human resource planning and employee performance in public hospitals in Kenya. The descriptors of Human resource planning included: succession planning; staff replacements; matching of skills with jobs and qualification which distinguishes it from the present study. In the same vein, Maina and Kwasira (2015) discovered a positive statistically relationship between human resource planning practice (whose descriptors were employee attraction and retention strategies) and employee performance. Also in support of the study is Anyadike (2013) who associated decline in employee productivity to the absence of human resource planning practice in the Nigerian public service. With the conceptual variations, all the studies, just like the current study demonstrate the positive influence that human resource planning has on employee performance or productivity.

\section{Conclusion}

This study was aimed at establishing the influence of human resource planning on lecturers' performance in Kenyan public universities. In conformity with the results of many previous studies, correlation results revealed a statistically significant positive correlation between human resource planning practice and lecturers' performance. Similarly, regression analysis revealed that enhancement of human resource planning practice can improve lecturers' performance. It is, therefore, recommended that public universities invest in human resource planning practice, owing to its benefits. The findings of the study will inform the formulation of effective and/or strengthening of human planning practice in public universities. Human resource management practitioners will better understand the interplay between human planning practice and employee performance. Researchers, organizational behaviourists and theorists will benefit from the body of knowledge so created.

\section{References}

Abba, H.D., \& Mugizi, W. (2018). Performance of academic staff in polytechnics: An analysis of performance levels in North West Geo-political zone of Nigeria. Arts and Humanities Open Access Journal, 2(3), 198-203. Doi: 10.15406/ahoaj.2018.02.00056

Abdullah, Z., Ahsan, N., \& Alam (2009). The effect of human resource management practices on business performance among private companies in Malaysia. International Journal of Business and Management, $4(6), 65-71$.

Adeyemi, S. B. (2017). Lectuerers' variables as predictors of academic performance in universities. Journal of Social Scienec,50(1-3), 14-26

Aguinis, H. (2009). Performance management. London: Pearson Prentice Hall.

Aila, F., \& Ombok, B. (2015). Validating measures in business research:Practical implications. International Journal of Science and Engineering, 1(9), 11-19.

Ajao, W. (2001). Cadbury is determined to move education forward. Vanguard, December 27, 2001, P. 16.

Ajayi, J.F.A. (1996). The African experience with higher education. The Association of African Universities, Accra. 
Alemu, S. K. (2018). The meaning, idea and history of university/ higher education in Africa: A brief literature review. Forum for International Research in Education,(4) 3, 210-227

Amimo, C. A. (2012). Tailoring higher education in Kenya to the demands of the post-industrial work place. Baraton Interdisciplinary Research Journal, 2 (1), 52-58.

Analoui, F. (2007). Strategic human resource management. London: Thomson Learning.

Anya, C.J.P., Umoh, G.I., \& Worlu, G. (2017). Human resource planning and organizational performance in oil and gas firms in Port Harcourt. International Journal of Advanced Academic Research Social \& Management Sciences, 3(9), 110-129.

Anyadike, N. O. (2013). Human resource planning and employee productivity in Nigerian public organizations. Global Journal of Human Resource Management, 1 (4), 56 -68

Armstrong, M. (2009). Armstrong's hand book of human resource management practice. (11 ${ }^{\text {th }}$ ed.). London: Kogan Page Ltd.

Armstrong, M. (2006). A Handbook of human resource management practice (10 thed.). London: Kogan Page. Arnold, I. J. M (2008). Course level and the relationship between research productivity and teaching effectiveness. Journal of Economic Education, 39(4), 307-21.

Arreola, R. A. (2000). Developing a comprehensive faculty evaluation system. Bolton, M.A: Anker Publishing Company, Inc.

Asiamah, N., Mensah, H. K., \& Oteng-Abayie, E. F. (2017). General, target, accessible population: Demystifying the concepts for effective sampling. The Qualitative Report, 22(6), 1607-1622. Retrieved from http://nsuworks.nova.edu/tqr/vol22/iss6/9

Ayiro, L. P. (2015, October, 3). The trouble with our varsities and how to sort them. Saturday Nation, Kenya, P.10-11.

Balam, E., \& Shannon, D. (2010). Student ratings of college teaching: A comparison of faculty and their students. Assessment and Evaluation in Higher Education, 35(2), 209-221.

Banerjee, A., Chaudhury, S., Singh, D. K., Banerjee, I., Mahato, A. K., \& Haldar, S. (2007). Statistics without tears: Inputs for sample size calculations. Industrial Psychiatry Journal, 16, 150-152.

Barney, J.B. (1991). Firm resources and sustained competitive advantage. Journal of Management, 17(1), 99120.

Barney, J.B. (2001). Resource-based theories of competitive advantage: A ten year retrospective on the resource-based view. Journal of Management, 27, 643- $\quad$ 650.doi:10.1177/014920630102700602

Bartlett, J. E., Kotrlik, J. W., \& Higgins, C. C. (2001). Organisational research: Determining appropriate sample size in survey research. Information Technology, Learning, and $\quad$ Performance Journal, 19(1), 1- 8.

Bedggood, R., \& Donovan, J. (2012). University performance evaluations: What are we really measuring? Studies in Higher Education, 37(7), 825-842.

Boxall, P. (1996). The strategic human resource management debate and the resource- based view of the firm. Human Resource Management Journal, 6 (3), 59 - 75.

Boxall, P. (1998). Achieving competitive advantage through human resource strategy: Towards a theory of industry dynamics. Human Resource Management Review, 8(3), 236-288.

Brumbach, G. B. (1998). Some ideas, issues and predictions about performance management. Public Personnel Management, Winter: 387 -402.

Butler, R. (1992). Designing organizations: A decision making perspective. London: Routledge.

Cadez, S., Dimovski, V. \& Groff, M. Z. (2017). Research, teaching and performance evaluation in academia: The Salient quality. Studies in Higher education,42(8), 1455-1473. Doi: 10.1080/03075079.2015.1104659.

Chege, E. N., \& Nasieku, T. (2018). Effect of human resource practices on employee performance in public hospitals in Kenya: A case of Nairobi County. International Journal of Social Sciences and Information Technology,(IV) V, 438-449.

Cole, G. A. (2009). Personnel and Human Resource Management ( $5^{\text {th }}$ Ed.). London: Cengage Learning.

Commission for University Education (2014a). State of University Education in Kenya. (1 $1^{\text {st }}$ ed.). Nairobi: CUE 
Commission for University Education (2014b). Harmonized criteria and guidelines for appointment and promotion of academic staff in Universities in Kenya. Nairobi: CUE

Commission for University Education (2016). Universities standards and guidelines, 2014. Nairobi:

CUE

Cooke, F. L. (2000). Human resource strategy to improve organizational performance: A route for British firms? ESRC Future Work Programme, Working Paper NO. 9. Manchester School of Management, UMIST.

Cooke, F. L. (2001). Human resource strategy to improve organizational performance: A route for firms in Britain? International Journal of Management, 3(4), 321-339.

Cooper, D., \& Schindler, P. (2008). Business research methods (10 $0^{\text {th }}$ ed.). Singapore: McGraw- Hill/Irwin.

Creswell, J. W. (2009). Research design: Qualitatitive, quantitative and mixed methods approaches $\quad\left(3^{\text {rd }}\right.$ ed.). London: Sage Publications Inc..

Creswell, J. W. (2014). Research design: Qualitative, quantitative, and mixed methods approaches. ( $4^{\text {th }}$ ed.). London: Sage Publications, Inc.

Drost, E. A. (2011). Validity and reliability in social science research. Education Research and perspectives, $38(1), 105-124$

Dugguh, S.I. \& Ayaga, D (2014). Job satisfaction theories: Traceability to employee performance in organizations. IOSR Journal of Business and Management, 16 (5), 11-18.

Ekwaoba, J. O., Ikeije, U. U., \& Ufoma, N. (2015). The impact of recruitment and selection criteria on organizational performance. Global Journal of Human Resource Management, 3(2), 22-33.

Farnham, D. (2006). Examiner's report (May), CIPD. co. Uk

Field, A. (2013) Discovering statistics using IBM SPSS Statistics: and sex and drugs and rock ' $n$ ' roll ( $4^{\text {th }}$ ed.). London: Sage

Fox, J. (1991). Regression diagnostics. Washington DC: Sage Publications, Inc.

Ganyaupfu, E. M. (2013). Factors influencing academic achievement in quantitative courses among business students of Private Higher Education Institutions. Journal of Education and Practice, 4(15), 57 - 65.

Gberebvie, D.E. (2006). Recruitment and quality academic selection: The case study of Covenant University. Ife Psychologia, 14 (2), 177-141.

Gberevie, E.S. (2010). Startegies for employee recruitment, retention and performance: Dimensionsof Federal Civil Service of Nigeria. African Journal of Business Management, 4(8), 1447-1456.

George, D. \& Mallery, P. (2003). SPSS for Windows step by step: A simple guide and reference. 11.0 update $\left(4^{\text {th }}\right.$ ed.). Boston: Allyn \& Bacon.

Gill, J., \& Johnson, P. (1997). Research methods for managers. London: Paul Chapman Publishing.

Gravetter, F. J., \& Wallnau, L.B. (2000). Statistics for the behavioral sciences ( $5^{\text {th }}$ ed.). Belmont: Wadsworth Thomson Learning.

Gudo, C.O., Oanda, I.O, \& Olel, M.A, (2011). Role of institutional managers in quality assurance: Reflections on Kenya's university education, Australian Journal of Business Management Research, 1(2), 113- 124.

Hill, L., Lomas, L., \& MacGregor, J. (2003). Students' perceptions of quality in higher education. Quality Assurance in Education, 11 (1), 15-20.

Ikama, A. (2010). Benefits and challenges of workforce diversity: A case study of Consultancy Group on International Agricultural Research Centres (CGIAR) in Kenya. Unpublished MBA Thesis, University of Nairobi, Nairobi - Kenya

Iyayi, F. I. O. (2002). Decision-Making in underdeveloped organizations: An exploratory investigation. Nigeria Journal of Business Administration, 4(1), 1-22

Johnson, D.R. \& Creech, J. C (1983). Ordinal measures in multiple indicator models: A simulation study of categorization error. American Sociological Review, 48(3), 398 - 407. Doi.org/10.2307/2095231.

Kaburu, J.K. (2014). An evaluation of quality of university education in Kenya during this massification era. Mediteterranean Journal of Social Sciences, 5(5), 345- 349

Kagondu, R., \& Marwa, S. M. (2017). Quality Issues in Kenya’s higher education institutions.

$J H E A / R E S A$ (15)1, 23-42 
Kamaara, E. K. (2011). Towards a culture of quality management at SASS, Moi University: Changing lecturers' attitudes to student assessment/QM. In Mayer, P., Wilde, M., Dinku, A., JuttaFedrowitz, J., Shitemi, N. L., Wahlers, M., Ziegele, F. (Eds.) Challenges for faculty management at African higher education institutions (pp. 15-32). Osnabrück, Germany:University of Applied Sciences. Retrieved April 15, 2013 from http://www.international-deanscourse.org/uploads/media/Challenges_for_faculty_management.pdf

Kamande, K. E., \& Gachunga, H.G. (2014). Influence of human resource planning on organizational performance: A case study of international organization for Immigration. International Journal of Innovative Social Sciences and Humanities Research, 2 (2), 81-92.

Kara, M. A., Tanui, E \& Kalai, J.M. (2020). Lecturer quality in public universities in Kenya. European Journal of Education Studies, 7(10), 302-324. Doi: 10.46827/ejes.v7i10.3306

Karia, A., Omari, S., Mwanaongoro, S., \& Ondieki, A. (2016). The role of human resource planning on performance of public water utilities ni Tanzania. African Journal of Business and Management, 2(1), $72-77$.

Katua, N. T., Mukulu, E., \& Gachunga, G.H. (2014). Effect of employee resourcing strategies on the performance of commercial banks in Kenya. International Journal of education and Research, 2(1), 1 - 20.

Keppel, G., \& Zedeck, S. (1989). Data analysis for research designs: Analysis of variance and multiple regression/correlation approaches. NY: W H Freeman/Times Books/ Henry Holt \& Co.

Kimberlin, C. L., \& Winterstein, A.G. (2008). Validity and reliability of measurement instruments used in research. American Journal of Health System Pharmacists 65, 2276- 2284. Doi:10.2146/ajhp070364

Kothari, C.R., \& Garg, G. (2014). Research methodology: Methods and techniques, (2 ${ }^{\text {nd }}$ ed.). New Delhi: New Age International (P) Ltd. Publishers.

Kothari, C.R., (2004). Research methodology: Methods and techniques, (3 ${ }^{\text {nd }}$ ed.). New Delhi: New Age International (P) Ltd. Publishers.

Layman, L., Williams, L., \& Slaten, K. (2007). Note self: Make assignment meaningful. Computer Science Education. North Carolina State University: Raleigh, N.C, USA.

Lemoine, P.A., Jenkins, W. M., \& Richardson, M. D. (2017). Global higher education: Development and implications. Journal of Education and Development, 1(1), 58-71.

Liu, O. (2012). Student evaluation of instruction: in the new paradigm of distance education. Research in Higher Education, 27(3), 309 - 327.

Maina D.K., \& Kwasira, J. (2015). Role of human resource planning practices on employee performance in County Governments of Kenya: A case of Nakuru County. International Journal of Economics, Commerce and Management, 3(5), $1569-1580$.

Martin, M., \& Anthony, S (2007). External quality assurance in higher education: Making choices. Fundamentals of Education. Plan No. 85, Paris:II-UNESCO

Mbiu, A.K., \& Nzulwa, J. (2018). Influence of human resource planning on employee governments in Kenya. The Strategic Journal of Business and Change Management

productivity in county Mintzberg, H. (1973). The nature of managerial work. New York: Harper and Row.

5(4), 193-214.

Molefe, G. N. (2010). Performance measurement dimensions for lecturers at selected universities: An international perspective. SA Journal of Human Resource Management, 8(1). Doi:10.402/sajhrm.v8i1.243.

Monette, D. R., Sullivan, T. J., \& Dejong, R. C. (2002). Applied social research: Tool for human services $\quad\left(5^{\text {th }}\right.$ ed.). California: Harcout College Publishers.

Mugenda, G.A. (2008). Social science research: Theory and principles, Nairobi: Applied Research and Training Services.

Mukhwana, E., Oure, S., Too, J. and Some, D. (2016). State of post graduate research training in Kenya. Nairobi: Commission for University Education.

Mwiria, K. \& Nyukuri, M.S. (1994). The management of double intakes: A case of Kenyatta University. Paris. UNESCO: International Institute of Educational Planning

Ngolovoi, M. (2006). Means testing of student loans in Kenya. Presented at the Comparative and International Higher Education Policy: Issues and Analysis Workshop: University at Albany. 


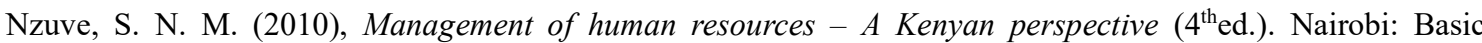
Modern management Consultants and Publisher.

O'Brien, R. M. (2007). A caution regarding rules of thumb for variance inflation factors. Quality and Quantity, 41, 673 - 690. Doi: 10.1007/s11135-006-9018-6

Oanda, I. O., \& Jowi, J. (2012). University expansion and the challenges to social developments in Kenya: Dilemmas and pitfalls. Journal of Higher Education in Africa, 10 (1), 49-71.

Ogunyomi, P. O., \& Ojikutu, R. K. (2014). Employee resourcing and performance of small and medium enterprises in Lagos State, Nigeria. Journal of Entrepreneurship and Business Innovation, 1(1). doi: 105296/jebi.

Omona, J. (2013). Sampling in qualitative research: Improving the quality of research outcomes in Higher Education. Makerere Journal of Higher Education, 4 (2), 169-185.

Onwuegbuzie, A. J., \& Collins, K. M. (2007). A Typology of Mixed Methods Sampling Designs in Social Science Research. The Qualitative Report, 12(2), 281-316. https://doi.org/10.46743/2160-3715/ 2007.1638

Orodho, J.A. (2005). Elements of education and social science research methods. Nairobi: Masola Publishers

Osborne, J.W., \& Waters, E. (2002). Four assumptions of multiple regression that researchers should always test. Practical Assessment, Research and Evaluation, 8(2), 1-5.

Oso,W.Y., \& Onen, D.(2013). A guide to writing research thesis and report .Nairobi: Satima Printers

Ponge, A. (2013). Graduate unemployment and un-employability in Kenya: Transforming university education to cope with market demands and the lessons for Africa. International Journal of Social Science Tomorrow, 2(3), 1-12.

Republic of Kenya (2007a). Kenya Vision 2030: the popular version. Nairobi: Government Printer

Republic of Kenya (2012). The Universities Act No. 42 of 2012. Nairobi: Government Printer

Riechi, A. R. O. (2010). Demand for academic programmes offered in Kenya public universities and their relevance to labour market. Retrieved February 12, 2013 from www.csae.ox.ac.uk/

Robinson, J. (2009). Triandis theory of interpersonal behaviour in understanding software privace behaviour in the South African context. Unpublished Masters Degree Thesis, University of the Witwatersrand.

Rubin, A. \& Babbie, E. (2001). Research methods for social work. Australia: Wadsworth.

Shulman, L. (1992).. Ways of seeing, Ways of knowing, Ways of teaching, Ways of learning about teaching. Journal of Curriculum Studies, 28, 393-396.

Simon, H.A. (1945). Administrative behaviour ( $2^{\text {nd }}$ Ed.). New York: Free Press.

Sinclair, H., \& Johnson, W. (2000). Students and staff perception of "good" teaching feedback. Educational Studies, 25(3), 1-5.

Sullivan, G., \& Artino, A. (2013). Analyzing and interpreting data from likert-type scales. Journal of Graduate Medical Education, 5 (4), 541-542. doi.org/10.4300/JGME-5-4-18

Tabachnick, G. G., \& Fidell, L. S. (2001). Using multivariate statistics. Boston: Harvard University Press.

Tavakol, M., \& Dennick, R. (2011). Making sense of Cronbach's alpha. International Journal of Medical Education, 2, 53-55. DOI: $10.5116 /$ ijme.4dfb.8dfd

Teixeira, A. (2002). On the link between human capital and firm performance: A theoretical and empirical survey. FEP Working Paper No. 121, November p. 1414-156

Tonwe, D.A. (1994). Public administration: An introduction. Ibadan: Amfitop Book Company.

Torrington, D., Hall, L., \& Taylor, S. (2008). Human resource management. England: Pearson Educational Ltd.

Umar, M. (2018). Research fundamentals: Study design, population, and sample size. URNCST Journal, 2(1), 1 7

Wangenge-Ouma, G. (2008).Higher education marketisation and its discontents: the case of quality in Kenya. Higher Education, 56: 457. doi:10.1007/s10734-007-9104-2

Wanzala, O. (2015, October, 3). Suspension of courses puts regulator on the spot. Saturday Nation, Kenya, P.11. 
Wanzala, W. (2013) Quest for quality and relevant higher education, training and learning in $\quad$ Kenya: An overview. Educational Journal, 2(2), 36-49.

Waweru, E. M. (2007). Management of human resources in Kenya. Nairobi: KLB.

White, A. (2008, 15, April). Managing academic performance: Understanding development in the academic environment. Guardian News and Media Limited, 1-29.

Whitley, B. E. (2002). Principals of research and behavioural science. Boston: McGraw-Hill

World Bank (1996). Teaching capacity in African Universities. Washington, DC: World Bank.

World Bank (2017). Higher Education for development: An evaluation of the World Bank group's support. Washington, DC: World Bank.

Yego H.C. (2016). Challenges facing higher education management of privately sponsored students programmes in Kenya. British Journal of Education 4(8), 52-62.

\section{Acknowledgement}

The authors acknowledge the management of Rongo University, Kenya for the research grant they awarded in favour of this study. 